DOI: $10.15290 /$ bsl.2020.17.05

\author{
Agnieszka Czyżak \\ Instytut Filologii Polskiej \\ Uniwersytet im. Adama Mickiewicza w Poznaniu \\ e-mail: agaczyz@amu.edu.pl \\ ORCID: 0000-0001-8918-5264
}

\title{
Czym bywa most Mirabeau - o śmierci (nie) w Paryżu
}

Most Mirabeau jest oczywiście budowlą użyteczności publicznej w stolicy Francji, pięknym zabytkiem z przeszłości, pomnikiem historii ${ }^{1}$. Spina brzegi Sekwany i łączy dwie dzielnice Paryża - widać z niego wieżę Eiffle’a, a na łuku rzeki przecinającej najbardziej znaną przestrzeń francuskiej stolicy znajduje się po przeciwległej stronie do katedry Notre-Dame. Zbudowano go w latach 1895-1897 - i jest świadectwem modernistycznych przemian w architekturze i sztuce urbanistycznej.

Bardzo wcześnie jednak jego historia złączyła się z literaturą. Już w roku 1913 - jeszcze przed I wojną światową - w tomie Alkohole Guillaume Apollinaire opublikował wiersz Le pont Mirabeau. Utwór od razu zyskał popularność - stał się też jedną z paryskich piosenek do dzisiaj śpiewanych przez francuskich bardów, a zatem i częścią tego specyficznego miejskiego folkloru $^{2}$. Zarejestrowane i dostępne w Internecie wykonania z reguły pokazują również sam most i przepływającą pod nim rzekę. Natomiast integralną częścią budowli stała się tablica $\mathrm{z}$ wyrytą na niej pierwszą strofą oraz refrenem

\footnotetext{
1 Most Mirabeau został oficjalnie uznany za historyczny zabytek narodowy w roku 1975 niemal przed półwieczem. Warto wspomnieć, że budowlę zdobią cztery alegoryczne rzeźby: Miasto Paryż, Obfitość, Handel i Nawigacja, których autorem był Jean Antoine Injalbert.

2 Zob. A. Arno, Apollinaire: łakomy i odrzucony, dwutygodnik.com, https://dwutygodnik.com/ artykul/1815-apollinaire-lakomy-i-odrzucony [dostęp 12.09.2020].
} 
wiersza, w którym Apollinaire dokonał swoistego połączenia strategii umiejscowienia doświadczeń z konwencjami lirycznego wyznania.

Nie trzeba przypominać, że Paryż jest jednym z miast-mitów, miast-symboli, wielu chciałoby wędrować po paryskim bruku, a „nad dachami Paryża” spoglądać w "paryskie niebo" - literatura, sztuka popularna, a później kultura masowa niezwykle często wykorzystywały przestrzeń miasta, zarówno jako wyrazisty element świata przedstawionego, jak i temat, pozwalający zgłębiać tajniki tego wyjątkowego miejsca. Wiele charakterystycznych budynków rozpoznawalnych jest na całym świecie, a należą do nich mosty nad Sekwaną, rzeką, po której niezliczona liczba łodzi przepływa pod ich łukami, pozwalając kontemplować także ich urodę. Paryż nie dzieli się na lewobrzeżny i prawobrzeżny - nurty rzeki nie rozcinają miasta, lecz są jedną z głównych arterii komunikacyjnych jego centrum.

W wierszu Apollinaire'a most Mirabeau jest punktem, z którego podmiot, obserwując przepływ wód rzecznych, doświadcza istoty przemijania. Utwór przy uważniejszym oglądzie okazuje się raczej tradycyjnym ujęciem tematu - płynąca woda symbolizuje upływający bezpowrotnie czas, a podmiot liryczny rejestruje ten proces ze stałego punktu czasoprzestrzeni. W tłumaczeniu - czy raczej dość nieudolnym spolszczeniu - Adama Ważyka jedna ze strof brzmi tak:

Niech dni się toczą jak rzeka wezbrana

Ni czas nie zawraca

Ni miłość pożegnana

Pod mostem Mirabeau płynie Sekwana ${ }^{3}$

Z kolei kończący każdą z czterech strof dwuwersowy refren zawiera wizję trwania podmiotu na przekór upływowi czasu:

Zegar niech dzwoni noc niech nastaje

Dni ulatują ja pozostaję

Rytmiczność powtórzeń tej deklaracji jednostkowego oporu wobec ludzkich przeznaczeń nie czyni wiersza optymistycznym - jest on raczej pełną melancholii obserwacją nieuchronnej utraty uczuć i ludzi, zarówno samych więzi międzyludzkich, jak i konkretnych osób. Refleksje snute w miejscu własnym, udomowionym, w rozpoznawalnym punkcie miasta, okazują się przede wszystkim ekspresją jednostkowej woli dystansowania się - dzięki Sztuce i poprzez nią - wobec ograniczeń ludzkiej kondycji.

3 G. Apollinaire, Most Mirabeau, przeł. A. Ważyk, „Kwartalnik Artystyczny” 2019, nr 3, s. 4. 
Śmierć w Paryżu dla jego mieszkańców jest oczywistym wydarzeniem, które musi nadejść jako kres żywota dokonujący się w przestrzeni codzienności. Dla rzeszy artystów, którzy tłumnie ściągali do francuskiej stolicy, przede wszystkim od wieku XIX do połowy XX, jako do centrum światowej kultury ${ }^{4}$, okazywała się końcem życia w przestrzeni wybranej, upragnionej ze względu na aurę twórczej wolności, swobodę wieloetnicznej różnorodności, na przyzwolenie dla wszelakich, bardziej lub mniej inspirujących pragnień, by eksperymentować, poszukiwać, przekraczać istniejące konwencje artystyczne, społeczne konwenanse i obyczajowe tabu.

W XXI wieku wiersz Apollinaire'a ponownie przetłumaczył Antoni Libera. Nie uczynił tego jednak z powodów estetycznych, alegacyjnych, potwierdzając tym samym rangę utworu czy też impulsów emulacyjnych, tak ważnych dla każdego tłumacza, próbującego „poprawić” istniejące translacje. Przekład powstał jako reakcja na pożar katedry Notre-Dame, który wybuchł 15 kwietnia 2019 roku - czytelnicy „Rzeczpospolitej” tuż po katastrofie otrzymali do ręki tekst z taką właśnie adnotacją. Wariant Libery, dokładniejszy i bardziej przemyślany pod względem rytmicznym niż wersja Ważyka, stał się swego rodzaju epitafium na „śmierć" katedry. Oto jego pierwsza strofa:

\author{
Most Mirabeau. A pod nim nurt Sekwany \\ Dawne miłości - \\ Ich czar wciąż wspominany \\ Te chwile szczęścia które leczy rany ${ }^{5}$
}

Refren z kolei (tym razem z rymem męskim) sugerował poszerzoną perspektywę oglądu procesów przemijania:

Noce i dnie - gdziekolwiek tu czy tam -

Mijają i pierzchają a ja trwam

Jak się zdaje gest Antoniego Libery był swoistą próbą dotknięcia substancji boleśnie "zranionego" miasta, pochwycenia w słowie - cudzym, a jednak własnym - jego fenomenu. Utwór, którego geograficznym umiejscowieniem był jeden z paryskich mostów, stał się tym samym opowieścią o nieoczekiwanej kruchości kamiennych, z pozoru niewzruszonych pomników historii.

\footnotetext{
4 Zob. P. Casanova, Światowa przestrzeń literacka, przeł. J. Misun, „Teksty Drugie” 2014, nr 6.

5 G. Apollinaire, Most Mirabeau, przeł. A. Libera, „Kwartalnik Artystyczny” 2019, nr 3, s. 5 (pierwodruk tłumaczenia został opublikowany w dodatku do „Rzeczpospolitej” - „Plus Minus” z dnia 19.04.2019).
} 
W wierszu ukraińskiej poetki Natałki Biłocerkiweć, urodzonej w połowie lat 50. XX wieku, a zatytułowanym My nie w Paryżu umrzemy most Mirabeau stał się nie tylko sygnałem intertekstualnego nawiązania, ale przede wszystkim wcielonym w kamień znakiem miejsca - niedostępnego, a przez to szczególnie upragnionego:

my nie w Paryżu umrzemy teraz na pewno to wiem w prowincjonalnej pościeli przesyconej potem i łzami i nikt ci nie poda twojego koniaku wiem że nikt nie pocieszy nas pocałunkami pod mostem Mirabeau mrok się nie rozejdzie kręgami ${ }^{6}$

Wiersze Biłocerkiweć w tłumaczeniu Bohdana Zadury - który zdaniem Tomasza Swobody „udzielił tym przekładom wielu dóbr, jakie znamy z jego poezji" 7 - okazują się z jednej strony głosem pokolenia, z drugiej zaś bezradnym wołaniem zza żelaznej kurtyny, naznaczonym środkowoeuropejskim poczuciem niespełnienia, braku, poczucia niższości. Stąd owo „my” sugerujące zbiorowy charakter doświadczenia. Liryk napisany w roku 1982 w oficjalnym obiegu mógł znaleźć się dopiero po przemianach politycznych z drugiej połowy lat 80 . XX wieku.

Utwór rozpoczynają wizje paralelne do tych z wiersza Apollinaire'a:

zacierają się linie zapachy barwy i dźwięki słabnie wzrok gaśnie słuch i radość najprostsza przemija obracasz za swoją duszą twarz i wyciągasz ręce lecz ona leci wysoko daleka i nieuchwytna

Jednak już kolejne obrazy ewokują przestrzeń determinowaną przez historię i konkret ówczesnej ukraińskiej codzienności, wprowadzając portret wspólnoty dotkniętej szczególnym rodzajem niemocy i bezradności. Zdaniem Magdaleny Rabizo-Birek gatunkiem często wybieranym przez Natałkę Biłocerkiweć był „erotyk polityczny" ${ }^{\prime}$ i z pewnością wiersz My nie w Paryżu umrzemy można do niego zaliczyć. Poetka zaczynała inny swój znany liryk stwierdzeniem: „Miłość w Kijowie straszniejsza jest od przepięknych / weneckich namiętności" ${ }^{\prime}$. Miłość zdegradowana do powierzchownych kontaktów w dotkniętej brzydotą i rozpadem przestrzeni okazuje się z reguły

\footnotetext{
6 N. Biłocerkiweć, Róża i nóż, przeł. B. Zadura, Rzeszów 2009, s. 29.

7 T. Swoboda, O wierszach Natałki Biłocerkiweć, w: N. Biłocerkiweć, Róża i nóż, s. 59.

8 M. Rabizo-Birek, Notatki ze spotkań z Natałkq Biłocerkiweć, „Twórczość” 2010, nr 6, s. 98.

9 N. Biłocerkiweć, Róża i nóż, s. 27.
} 
działaniem zastępczym - nie przynoszącym szczęścia i nie uwznioślającym kochanków.

Obroną przed poczuciem uwięzienia $\mathrm{w}$ niemożliwych do zaakceptowania realiach mogłaby się stać poezja, jako możliwość ekspresji świadomego siebie i swojej sytuacji „,ja", zdolnego przynajmniej rejestrować świat i wnikać w tajniki ludzkich przeznaczeń. Joanna Ślósarska przekonywała:

Poetyckie światoobrazy Natałki Biłocerkiweć można najtrafniej określić za Hugo Friedrichem, gdy zauważa on, że „liryka jest tajemnicą, granicznym pasem, wydartym temu, co nie do wysłowienia, jest cudem i siłą gwałtowną". Ów "pas graniczny" w wersach Natałki Biłocerkiweć przekształcany jest w rozległe terytorium, na którym żyje się najpełniej ${ }^{10}$.

Rozległe terytorium liryki, czy szerzej sztuki słowa mogło stać się odosobnionym matecznikiem, ograniczoną sferą wolności - paradoksalnie jednak właśnie $\mathrm{z}$ tej perspektywy dotkliwiej widać było ograniczenia $\mathrm{w}$ realnej przestrzeni.

W inny sposób podobne doświadczenia $\mathrm{z}$ tamtego czasu przekładał na język liryki Antoni Pawlak. Napisał on wówczas cykl wierszy, w których Paryż stał się nie tyle miejscem upragnionym, ile niemożliwym do wyobrażenia dla mieszkańców Wschodu. W wierszu Trudno o lepsze wyttumaczenie pada nawet sugestia, iż Paryż nie istnieje. Podmiot liryczny, patrząc na fotografię ze stolicy Francji, stwierdza: „ten obrazek wygląda realnie / a przecież nie ma Paryża"11, wszystkie kolorowe pocztówki to zwykłe oszustwo „handlarzy marzeniami”. Wobec namacalnej realności stolicy wschodniego imperium francuskie miasto staje się podobne onirycznym majakom i dlatego „Moskwa to nie Paryż" (Z Paryża list pierwszy), bowiem to ona jest „realna jak kolczasty drut"12.

Paryż okazuje się miejscem, w którym dokona się symboliczna zagłada Zachodu, zdeptanego przez barbarzyński Wschód. W utworze Paryż - rok końca świata pojawia się wizja końca cywilizacji:

Paryż to nie lukrowana wstążka Sekwany ani tłum kościołów czworobok katedr

[...]

jest rok 1984 zgodnie z przepowiedniami nadciąga zagłada

być może w korytarzach pod miastem uda się coś ocalić ${ }^{13}$

\footnotetext{
10 J. Ślósarska, Od tekstu do wiersza, w: N. Biłocerkiweć, Róża i nóż, s. 6.

11 A. Pawlak, Kilka słów o strachu (1983-1985), Kraków 1990, s. 24.

12 Tamże, s. 25.

13 Tamże, s. 28-29.
} 
Pozbawiona pewności nadzieja, że w chtonicznej przestrzeni pod zburzonym miastem uda się uchronić resztki zachodniej cywilizacji w pewnym stopniu osłabiała wymowę apokaliptycznych wizji. Wolność lirycznej wyobraźni nie łagodziła jednak poczucia uwięzienia $\mathrm{w}$ realiach opresyjnego systemu ${ }^{14}$. Z perspektywy polskich doświadczeń stanu wojennego nadciągająca zagłada miasta-symbolu wydawała się niepokojąco prawdopodobna, jako znak końca znanego nam kulturowego porządku.

W wierszu Jorge Luisa Borgesa zatytułowanym Paryż 1856 (napisanym w latach 60. XX wieku) tematem jest śmierć Heinricha Heinego w stolicy Francji, potraktowana jako znak wygnańczego losu twórcy niezrozumianego i odrzuconego przez współczesnych:

Przyzwyczaiło go umęczenie długie do przedsmaku śmierci. Ogarnąłby go strach, na myśl, że musi wyjść do wrzaskliwego dnia i chodzić, przechadzać się pomiędzy ludźmi. Powalony, Henryk Heine myśli o tej rzece, o czasie, co z wolna unosi go i oddala od życia półmroku, i tego, co jest jak rana, losu: bycia człowiekiem i Żydem jeszcze. [...] Nie, nie uratuje cię: twoje słownikowanie, twoje ze złota noce i kwiaty opiewane ${ }^{15}$.

Zgon schorowanego poety jawi się jako wyzwolenie z marności ziemskiego trwania, choć nie ma mocy usunięcia piętna wykluczenia. Płynąca nieprzerwanie rzeka i upływający nieodmiennie czas nie stają się elementami artystycznej wizji przekraczania ludzkich przeznaczeń, lecz ich nieuchronności. Śmierć w Paryżu nie uwzniośli też długiego konania,

Natomiast utwór Natałki Biłocerkiweć kończą słowa:

nigdy nam nie pozwolą umrzeć w Paryżu drogę do mostu Mirabeau kordonem szczelnym otaczając

Przedarcie się przez kordony do Paryża realnego nie było możliwe - miasto i most nad Sekwaną pozostały wyrazistym znakiem zniewolenia, którego

14 Zob. A. Czyżak, Czytane po trzydziestu latach. O wierszach Antoniego Pawlaka z lat osiemdziesiatych, w: Sopot w literaturze. Literatura w Sopocie, red. J. Mosakowski i in., Gdańsk 2019.

15 J.L. Borges, Paryż 1856, przeł. E. Stachura, w: E. Stachura, Wiersze, poematy, piosenki, przekłady, Warszawa 1982, s. 350. 
przemożną siłę zwalczać można było jedynie w sferze mentalnej. W wierszu dochodzi do desperackiego wręcz odrzucenia toposu „składania kości w ojczystej ziemi", czyli pragnienia towarzyszącego z reguły wygnańcom i tułaczom pozbawionym możliwości powrotu do kraju rodzinnego ${ }^{16}$.

Mottem wiersza uczyniła Biłocerkiweć wers z utworu Cesara Vallejo Czarny kamień na biatym kamieniu: „Umrę w Paryżu w czwartek wieczorem”. W tym sonecie zapowiedź śmierci w stolicy Francji nie jest przepowiednią rychłego zgonu, lecz deklaracją wyboru miejsca, w którym powinien nastąpić. I znów ważny okazuje się w tym przypadku kontekst geobiograficzny czy też topobiograficzny. Cesar Vallejo przybył do Paryża w roku 1923, kiedy to wyjechał na zawsze $z$ Peru, po odsiedzeniu kilkumiesięcznego wyroku wydanego z przyczyn politycznych. Ale i z Paryża został wydalony - znów z powodu poglądów, czyli świeżo nabytej wiary w marksizm - i trafił do Hiszpanii. Jednak poecie (jak piszą o nim autorzy notek biograficznych) udało się ostatecznie umrzeć w Paryżu, choć nie w czwartek wieczorem.

I tu pojawia się pytanie o tę śmierć, którą "udało się" wpisać w zaprojektowaną przestrzeń - bo przecież i tak nie udało jej się „przeżyć” w Paryżu. Czy warto bowiem zastanawiać się, "gdzie" nastąpi śmierć, czy raczej powinniśmy obawiać się „,jak" i w jakich warunkach do niej dojdzie? Wybór miejsca zgonu - czy jak w przypadku Biłocerkiweć niemożność podjęcia takiej decyzji - staje się zatem gestem swoistego zawłaszczania przestrzeni. Czy zatem „miejscem autobiograficznym” jest bardziej to, w którym się żyje, czy to, które jest wymarzoną scenerią odejścia ze świata? I jak na ogląd tych problemów wpływa poczucie zbliżającego się kresu cywilizacji?

Ponowoczesna opowieść o świecie jawiła się przez dekady jako tekst pozbawiony wyrazistego początku i końca, czyli punktu dojścia - funkcjonowała raczej jako historia posiadająca wiele możliwych złych zakończeń. Na przykład Ewa Mazur na początku XXI wieku w szkicu Bez końca albo koniec $i$ początek twierdziła:

Paradoksalnie modernizm, mimo nadrzędnej konstatacji, że koniec jest początkiem, respektował tradycyjną wizję sekwencyjności i linearności czasu, ciągłości trwania. Historia - miała być ciągiem powtarzalnych układów zdarzeń o linearnym, uporządkowanym przebiegu. [...] W opowieściach postmodernistycznych brak jest modernistycznej linearności - sekwencyjność fabuły wzbogacona została o wątki rozwijane równolegle i niezależnie (niestanowiące

16 Można przypomnieć w tym miejscu liczne świadectwa polskich emigrantów, którzy nie chcieli umierać w Paryżu - od polskich romantyków po pisarzy dwudziestowiecznych (takich jak na przykład Kazimierz Brandys, mieszkający tam od lat 80. zeszłego wieku), którzy stolicę Francji traktowali jak miejsce pobytu przymusowego i tymczasowego). 
dopełnienia). Nielinearność opowieści polega między innymi na tym, że małe "historie" nie sumują się w "Historię", fragmenty nie składają się w żadną całość $^{17}$.

Linearne widzenie czasu prowokowało do tworzenia albo optymistycznych obrazów nieustannego progresu ludzkości albo pesymistycznych, apokaliptycznych wizji końca, momentu, w którym cały świat ulega zagładzie, w błysku wybuchu, w kuli ognia, w huku totalnej katastrofy.

Ponowoczesność natomiast tworzyła niezliczone obrazy kresu, który stał się procesem zamierania sił żywotnych cywilizacji, rozpadu porządkujących ją hierarchii wartości, entropii sensu. $W$ dodatku proces ten nie był jednym nurtem prowadzącym ku ostatecznemu rozproszeniu, lecz tworzyła go niezliczona ilość splątanych strumieni bytów zmierzających nieuchronnie, choć nieprzewidywalnymi meandrami ku zagładzie. Prawidłowością niemal wszystkich opowieści o entropii było usytuowanie w jej centrum medium, którego jednostkowe doświadczenie i osobista perspektywa oglądu okazywała się ostatecznie jedyną instancją scalającą wizję. Najczęściej jednak zaklinanie rozpadającej się rzeczywistości słowem nie było $\mathrm{w}$ stanie jej ocalić, pomagało jedynie przybliżyć fragmenty jednostkowej pamięci o minionym.

Z tej perspektywy umiejscowiona śmierć, ukazywana w przestrzeni Paryża jako przestrzeni oczywistej, wybranej lub wymarzonej $\mathrm{w}$ wierszach rozbitków z różnych obszarów globu była wciąż jeszcze śmiercią modernistyczną - mieszczącą się w nadrzędnych wobec jednostki porządkach. Sytuowanie własnego zgonu w konkretnym miejscu łączy się z wiarą w możliwość nadania mu znaczenia i podporządkowania woli jednostki - a zarazem przekształcenia w gest artystyczny, zarazem osobisty, jak i skierowany ku wspólnocie. Jednak z punktu widzenia naszych obecnych doświadczeń należałoby zadać pytanie: komu dziś jeszcze mogłoby zależeć, aby umrzeć akurat w Paryżu?

Coraz bardziej powszechna świadomość nadchodzącego końca ludzkości realizuje się dziś nie $\mathrm{w}$ wieszczbach pojedynczych proroków rozpadu, lecz w produkowanych na potrzeby kultury masowej "atrakcyjnych" wizualnie i już stereotypowych obrazach kosmicznych lub ekologicznych (klimatycznych) katastrof niszczących Ziemię. Równolegle powstają nadal wizje powolnego, lecz nieuchronnego, dochodzenia cywilizacji do kresu, wymierania ludzkiego gatunku - choć teraz skraca się perspektywa oglądu

17 E. Mazur, Bez końca albo koniec i początek. O ponowoczesnym rozumieniu sytuacji schyłkowej, w: Punkt po punkcie. Koniec, red. A. Czekanowicz, S. Rosiek, Gdańsk 2006, s. 178-179. 
nadchodzącej zagłady, która zdarzyć się może już w obecnym, XXI wieku. Mieszczą się one jednak wciąż pomiędzy wizją z Piosenki o końcu świata, wczesnej, bo tużpowojennej diagnozy Czesława Miłosza, której puenta wyraża przekonanie, iż innego, niż zwyczajny, codzienny, niezauważalny końca świata nie będzie, a pozornie konsolacyjną diagnozą "bezsilności” śmierci z wiersza Wisławy Szymborskiej O śmierci bez przesady: „Nie ma takiego życia, / które by choć przez chwilę / nie było nieśmiertelne"18. Ta przepojona łagodnym sarkazmem konsolacyjność utworu okazuje się jednak gorzką wiedzą o nieuchronności śmierci, przed którą uciec można jedynie na chwilę. $W$ tej sytuacji przed grozą istnienia wciąż może chronić ironiczny dystans, zdolny (na krótko) przesłonić strach przed ostatecznym wyrokiem.

Mamy dziś jednak do czynienia ze swoistym sprzężeniem zwrotnym powszechna świadomość zbliżającego się kresu skłania twórców nie tylko do jego tematyzowania w coraz liczniejszych wariantach, ale i do tekstowego symulowania entropii, zagarniającej kolejne elementy utworów. Zwiększająca się liczba tak zaprojektowanych literackich diagnoz rozpadu współtworzy $\mathrm{z}$ kolei zbiorowy ogląd zjawiska. Proces ten rozgrywa się $\mathrm{w}$ dodatku w ramach kultury wyczerpania i powtórzenia. Dla Ewy Mazur, snującej swoje rozważania na przełomie XX i XXI wieku wszechobecna gra, koncept, ostentacyjna tekstowość kreowanych współcześnie światów była jeszcze ocenianą negatywnie rezygnacją z pełnego powagi namysłu nad ludzką kondycją, bowiem - jak twierdziła - multiplikując śmierć, staraliśmy się po prostu ją unieważnić, by przesłonić poczucie bezradności. A tym samym:

znaleźliśmy się w pułapce ponowoczesności, pułapce, której postmodernizm nie stworzył, ale którą przed nami odkrył. Okazuje się bowiem, że sytuacja schyłkowa jest constans, żyjemy w stanie permanentnego schyłku świata, rozkładu kultury, umierania, z którego możemy żartować, które możemy zaklinać lub potraktować wzruszeniem ramion [...]. Ale ten schyłek będzie trwał. Bez końca. A co za tym idzie - bez szans na początek ${ }^{19}$.

Dziś wiemy już, że także wiara w „długie trwania" owej schyłkowości okazała się złudzeniem. Rozdział pomiędzy modernistycznym i postmodernistycznym widzeniem czasu i dziejów świata ulega obecnie unieważnieniu. $\mathrm{W}$ tej sytuacji poczucie trwałości (choćby złudne) znaleźć można na drodze indywidualnych poszukiwań i odkryć.

18 W. Szymborska, Widok z ziarnkiem piasku, Poznań 1996, s. 111.

19 E. Mazur, Bez końca, albo koniec i początek, s. 182. 
Niepewność przyszłości, ciążące nad ludzkością coraz wyraźniejsze widmo globalnej katastrofy mimo wszystko skłania więc do szukania jakichkolwiek umocowań, także tych przestrzennych, dla jednostkowego - kruchego i niepewnego - trwania "na przekór". W eseju Mapa. Prolegomena Andrzej Niewiadomski stworzył wizję „bycia-wewnątrz-mapy” jako szczególnego sposobu na zbudowanie (osobistego i warunkowego) fundamentu samowiedzy, a zatem i zdolności akceptowania własnego miejsca na ziemi ${ }^{20}$. Tekst dowodzi, że mapa bywa przede wszystkim przemożnym impulsem do tworzenia niezliczonych narracji - skłania do przyjmowania innych perspektyw oglądu, ułatwia odnajdywanie nowych przebiegów (znanych) opowieści, własnych i cudzych. Jednocześnie pozwala pozostawać twórcy w centrum samodzielnie rozrysowywanej mapy, ujawniać moc kreacyjną - tożsamą z autokreacyjną.

Esej Mapa. Prolegomena okazuje się tym samym szczególną symulacją prób uporządkowania wiedzy o istocie (esencji i egzystencji) "mapy”, istnienia $\mathrm{w}$ jej ramach, pozostaje jednak historią jednostkowego wpisywania się $\mathrm{w}$ jej uniwersalizujący porządek, sytuowania się wobec reguł ustalanych poprzez jej wielorakie "objawienia" w tekstach kultury, poszukiwania granic własnej tożsamości. Proces dookreślania tych granic niejako wtórnie może przekształcać się w tworzenie bardziej uogólnionych reguł egzystencji, które jednak nie stają się zbiorem (projektem) nakazów. Utwór zdaje się bowiem także wyrazistym wskazaniem na poznawcze ograniczenia człowieka usiłującego zakreślać granice własnego terytorium - tym samym jest dla odbiorcy wyzwaniem do podjęcia samodzielnej, skierowanej ku jego własnym potrzebom próby powtórzenia gestu autora.

Oswajanie przestrzeni staje się z reguły „umiejscowieniem” siebie (mającym charakter procesualny i wielopłaszczyznowy) w niej i wobec niej. Elżbieta Rybicka, właśnie analizując tekst Niewiadomskiego i jego wariant sylleptycznej (autobiograficznej i tekstowej) podmiotowości, stwierdziła:

Syllepsa wprowadza zatem $\mathrm{w}$ obszar tworzący splot realnego $\mathrm{z}$ wyobrażonym, a dzięki temu kryptonimuje także główną regułę geopoetyki - zawieszenie pomiędzy biegunami "geo" i poiesis. Chodzi tu o zachowanie równowagi, a zarazem napięcia pomiędzy podmiotem (biografia), rzeczywistością (geografia) a językiem (twórczością literacką, wyobraźnią) bez rugowania któregokolwiek $\mathrm{z}$ elementów tej dynamicznej konfiguracji ${ }^{21}$.

20 A. Niewiadomski, Mapa. Prolegomena, Lublin 2012, s. 251.

21 E. Rybicka, Geopoetyka. Przestrzeń i miejsce we wspótczesnych teoriach i praktykach literackich, Kraków 2014, s. 163-164. Badaczka opisuje skutki eksperymentów z mapą czynionych przez Niewiadomskiego, twierdząc, iż jego esej problematyzuje zasadę odniesienia do realnej przestrzeni, ale jej nie unieważnia. 
Punktem dojścia podjętych prób destabilizowania najrozmaitszych sposobów pojmowania mapy byłaby „mapa eksperymentalna jako niedefinitywna potencjalność", której zadaniem byłoby projektowanie ruchu pomiędzy deterytorializacją i reterytorializacją, między "geo" i poiesis ${ }^{22}$.

Miejscem własnym stawać się mogą bowiem nie tylko miejsca doświadczane, ale i poznane za pośrednictwem istniejących tekstów, odtwarzane i wyobrażane. Podobnie rzecz się ma z przestrzeniami przynależącymi do fikcji, które urealniają się $\mathrm{w}$ aktywnym odbiorze, gotowe do zawłaszczenia i włączenia $\mathrm{w}$ obręb intymnego, duchowego terytorium. Małgorzata Czermińska, rozważając specyfikę literackich miejsc autobiograficznych, czyli znaczeniowych, symbolicznych odpowiedników rzeczywistych miejsc (wraz z ich kulturowymi wyobrażeniami) wskazywała na dwa warunki ich tekstowego zaistnienia. Skłonności do pisania $\mathrm{w}$ perspektywie osobistej musi towarzyszyć dar odpowiedniej „przestrzennej” wyobraźni twórcy ${ }^{23}$. Natomiast swoistym "punktem przecięcia" między pamięcią i wyobraźnią a światem realnym mogą stać się konkretne miejsca i budowle (takie jak choćby most Mirabeau), których obecność w tekście staje się znakiem ich podwójnej przynależności: do sfery doświadczeń (wyobrażeń) jednostkowych oraz do wspólnej sfery kulturowego (tekstowego i materialnego) dziedzictwa.

Wędrowanie szlakami wyznaczanymi przez teksty kultury oraz krzyżujące się z nimi meandry pamięci wskazuje cel podróży: poszukiwanie znaków, drogowskazów, pozwalających nie tylko docierać do obranych celów, ale i określić własną lokalizację. Przedzieranie się przez rozmaite dyskursywnie funkcjonujące tematy przestrzenne nie jest celem samym w sobie - zmienia się w próbę wytyczenia własnych dogodnych szlaków, ustawienia aktualnie przydatnych słupów granicznych, zarysowania reguł jednostkowo sankcjonowanego, tymczasowego porządku. Niewiadomski jako narrator „opowieści kartograficznych", podobnie jak jego poprzednicy, doceniał potęgę i niezbywalną przydatność wyobraźni, koniecznej do wykreślania map własnego, oswojonego emocjonalnie i intelektualnie świata. Wiedział także, że pomoc odnaleźć można w najbardziej nieoczekiwanych miejscach-tekstach:

\footnotetext{
22 Tamże, s. 166.

23 M. Czermińska, Miejsca autobiograficzne. Propozycja w ramach geopoetyki, „Teksty Drugie” 2011, nr 5, s. 188. Badaczka następnie charakteryzuje w tym miejscu posiadających wskazane cechy pisarzy jako „skłonnych do obserwowania świata zewnętrznego, obdarzonych dużą wrażliwością zmysłową, zainteresowanych bogactwem konkretu, z wyczuciem znaczenia materialnego szczegółu [...]. Ciekawi ich widzialny świat, w którym odczytują jego różnorodność, piękną i dziwaczną albo straszną. Albo szukają ukrytych w nim śladów przeszłości".
} 
Bez pomocy wyobraźni niemożliwe byłoby ustalenie własnego położenia, choć na pozór wydaje się, że wystarczy kilka prostych narzędzi. Nie zapominajmy jednak o "poetyckiej starzyźnie”, o której pisał Rimbaud. Nie tylko poetyckiej. Wskazówki, co do wyobraźni znajdujemy czasem w najbardziej zaskakujących miejscach, także tam, gdzie plecie się trzy po trzy ${ }^{24}$.

Staroświecka czy też uznawana za anachroniczną (spetryfikowaną, martwą) opowieść może odsłonić swą użyteczność. Odkrycie jej „wyobraźniowej" proweniencji mogłoby pozwolić na nowe, najbardziej osobiste odczytanie $^{25}$.

Wyobraźnia, wiodąca z reguły do tworzenia wizji o charakterze przestrzennym, może okazać się przydatna do wznoszenia ich konstrukcyjnych szkieletów (świadomie dookreślanych porządków). Pojmowana jako jedna z form aktywności psychicznej człowieka, służy przede wszystkim do wykorzystywania i przetwarzania doświadczeń życiowych. To właśnie wyobraźnia kierowana impulsem mapy zdolna jest tworzyć „mentalne całości”, których zadaniem nie jest jedynie czcza, spekulatywna gra z tekstami pochodzącymi z różnych pokładów tradycji, lecz podejmowanie kolejnych prób uspójnienia doświadczeń. Egzystowanie w przestrzeni podlegającej wielorakim przekształceniom skłania do nieustannego uaktualniania jej odwzorowań, poszukiwania punktów „stałych” (geograficznie i kulturowo), a zarazem diagnozowania skali przemian.

Konieczność uznania, iż ontologiczny status rzeczywistości (i nas samych) pozostaje niepoznawalny nie powinna przecież stawać się punktem dojścia rozważań. Stąd inna konieczność - odnajdywania (choćby ułomnych i niekonsekwentnych) sposobów przeciwstawiania się ograniczeniom, które mogą z kolei (paradoksalnie) okazywać się tożsame ze sposobami godzenia się na istnienie $\mathrm{w}$ stanie permanentnego zanikania. „Bycie-w-mapie” okazuje się gestem samostanowienia, a największą zaletą mapy zdaje się nadto jej zdolność do porządkowania horyzontalnego, co umożliwia odrzucenie hierarchii wertykalnych.

Paryż jest z pewnością wyrazistym punktem tak pojmowanej mapy. Punktem, który w wieloraki sposób można uczynić istotnym. Jak stwierdziła Aleksandra Kunce, pisząc o przestrzeni ludzkiego doświadczenia, które „punktowo naznacza człowieka”:

\footnotetext{
24 A. Niewiadomski, Mapa. Prolegomena, s. 143.

25 Zob. A. Czyżak, Niewiadomszczyzna, w: „Wreszcie nie pojawia się nikt”. Szkice o twórczości Andrzeja Niewiadomskiego, red. A. Jarzyna i in., Lublin 2016.
} 
Punkt to miejsce, w którym pulsuje życie. Otwiera się na nieskończone trajektorie, ciąży ku innym punktom, tworzy sieci odniesień, jawi się jako ruchliwy, a nie statyczny. „Punkt otwiera świat” - również w tym, że otwiera przestrzeń interpretacji, łącząc porządki natury, życia społecznego i metafizycznego istnienia ${ }^{26}$.

Paryż jako miasto niezwykłe, jedyne w swoim rodzaju, jest z pewnością punktem, w którym zbiegają się niezliczone trajektorie spisywanych przez wieki doświadczeń - punktem realnej przestrzeni, ważnej i dla tych, którzy nigdy nie stanęli na francuskiej ziemi. Przechodząc przez most Mirabeau nad nurtami Sekwany, niezależnie, czy czynimy to w rzeczywistości, w marzeniach, czy też wirtualnie, otwieramy szeroką przestrzeń interpretacji. Dziś jednak z pogłębiającą się obawą, że na takie doświadczenia pozostało nam niewiele czasu.

\section{Bibliografia}

Apollinaire Guillaume (2019), Most Mirabeau, przeł. A. Ważyk, „Kwartalnik Artystyczny", nr 3 (103), s. 4.

Apollinaire Guillaume (2019), Most Mirabeau, przeł. A. Libera, „Kwartalnik Artystyczny", nr 3 (103), s. 5.

Arno Anna (2020), Appolinaire: łakomy i odrzucony, dwutygodnik.com, https://www. dwutygodnik.com/artykul/1815-apollinaire-lakomy-i-odrzucony [dostęp 12.09. 2020].

Biłocerkiweć Natałka (2009), Róża i nóż, przeł. B. Zadura, Rzeszów: Stowarzyszenie Literacko-Artystyczne „Fraza”.

Borges Jorge Luis (1982), Paryż 1856, przeł. E. Stachura, w: E. Stachura, Wiersze, poematy, piosenki, przekłady, Warszawa: Czytelnik, s. 350.

Casanova Pascale (2014), Światowa przestrzeń literacka, przeł. J. Misun, „Teksty Drugie”, nr 6, s. 222-248.

Czermińska Małgorzata (2011), Miejsca autobiograficzne. Propozycja w ramach geopoetyki, „Teksty Drugie", nr 5, s. 183-200.

Czyżak Agnieszka (2016), Niewiadomszczyzna, w: „Wreszcie nie pojawia się nikt”. Szkice o twórczości Andrzeja Niewiadomskiego, red. A. Jarzyna i in., Lublin: Ośrodek Brama Grodzka, s. 19-28.

Czyżak Agnieszka (2019), Czytane po trzydziestu latach. O wierszach Antoniego Pawlaka $z$ lat osiemdziesiatych, w: Sopot w literaturze. Literatura $w$ Sopocie, red. J. Mosakowski i in., Gdańsk: Wydawnictwo Uniwersytetu Gdańskiego, s. 319-334.

Kunce Aleksandra (2016), Człowiek lokalny. Rozważania umiejscowione, Katowice: Wydawnictwo Uniwersytetu Śląskiego.

26 A. Kunce, Człowiek lokalny. Rozważania umiejscowione, Katowice 2016, s. 41. 
Mazur Ewa (2006), Bez końca albo koniec i początek. O ponowoczesnym rozumieniu sytuacji schyłkowej, w: Punkt po punkcie. Koniec, red. A. Czekanowicz, S. Rosiek, Gdańsk: Słowo/Obraz Terytoria, s. 176-182.

Niewiadomski Andrzej (2012), Mapa. Prolegomena, Lublin: Ośrodek Brama Grodzka. Pawlak Antoni (1990), Kilka słów o strachu (1983-1985), Kraków: Oficyna Literacka.

Rabizo-Birek Magdalena (2010), Notatki ze spotkań z Natałkq Biłocerkiweć, „Twórczość”, nr 6, s. 97-99.

Rybicka Elżbieta (2014), Geopoetyka. Przestrzeń i miejsce we współczesnych teoriach i praktykach literackich, Kraków: Universitas.

Swoboda Tomasz (2009), O wierszach Natałki Biłocerkiweć, w: N. Biłocerkiweć, Róża i nóż, Rzeszów: Stowarzyszenie Literacko-Artystyczne „Fraza”, s. 57-59.

Szymborska Wisława (1996), Widok z ziarnkiem piasku, Poznań: Wydawnictwo a5.

Ślósarska Joanna (2009), Od tekstu do wiersza, w: N. Biłocerkiweć, Róża i nóż, Rzeszów: Stowarzyszenie Literacko-Artystyczne „Fraza”, s. 5-6.

\title{
Whatever the Mirabeau Bridge Used to Be: About Death (Not) in Paris
}

\begin{abstract}
This article presents the connections between geography and literature leaning on the material of texts written in the $20^{\text {th }}$ century by authors from many different countries. Poems from the body of work by Guillaume Apollinaire, César Valejo, Jorge Luis Borges, Natałka Biłocerkiweć, Antoni Pawlak and their common main theme "death in Paris" are treated as examples of unique and significant evidence of the human experience of space. The interpretations of those literary creations may help us to understand the processes of locating a single existence. This is understood as a path that leads to self-awareness.
\end{abstract}

Keywords: Paris, death, place, geography, space, location 